Language, Locality, and Transnational Belonging: Remitting the everyday practice of cultural integration

Félix Krawatzek \& Gwendolyn Sasse

Department of Politics and International Relations \& Nuffield College, University of Oxford 


\section{Language, Locality, and Transnational Belonging: Remitting the everyday practice of cultural integration}

This paper explores how 'ordinary' German migrants in the United States reflected upon their local integration into society and transnational belonging on the basis of language practice in the period 1820-1970. At the heart of our qualitative and quantitative text analysis is a set of approximately 8,000 letters sent by around 700 German-speaking migrants who wrote, over varying time periods, to family members and friends still living in their places of origin. These letters provide insights into the migrants' transnational communication networks over an extended time and from across the United States. Until the emergence of a fully centralised bureaucracy in the US during the interwar period, most legislation affecting the living conditions of migrants varied significantly between US states. This raises the question to what extent the practices and narratives of belonging captured in the personal letters vary accordingly across locations, especially with regard to the balance between local and transnational belonging. Tracing this variation in subnational destination characteristics, our paper argues that feelings of transnational belonging are not directly responsive to shifts in political conditions and resulting policies. The maintenance of bilingualism or German community ties expressed in the letters also conveys an everyday practice of resistance or adaptation to local language policies in the US and remits concrete ideas about what it means to uphold a German identity in this specific migratory context.

Keywords: integration, transnational belonging, language policy, transnationalism, transatlantic migration, German-US migration, political remittances, migrant letters 


\section{Introduction}

How different groups of migrants within one country diverge in their integration and transnational engagement has attracted significantly more attention in social science research than how different political and economic conditions impact on the same group of migrants. ${ }^{1}$ Sub-national variation in the policies and local contexts affecting migrants' sense of belonging to their places of origin and residence has remained underexplored. Historically, this policy variation existed in the United States in particular prior to the development of a fully-fledged bureaucratic state during the interwar period and in the aftermath of World War II.

In this paper, we analyse the variation in destination characteristics in four US states (Illinois, Wisconsin, Ohio and Missouri) and the corresponding local and transnational narratives of belonging as reflected in migrant letters. These letters are an important source of remittances, transporting political but also social, cultural and economic practices, values and ideas across the Atlantic (Krawatzek and MüllerFunk this issue, Krawatzek and Sasse 2018c). Writing about whether or not one continues to actively use the German language and maintain community ties structures the political vocabulary and the political practices that migrants remit. Practices and vocabulary, interconnected through the letters, reflect the transnational belonging of the migrants and provide a new vocabulary for thinking about identity among the recipients of the letters. These letters were the main and often the only means of communication between those separated after migration and are therefore a source which greatly influenced what recipients thought about the host and origin societies. We focus on a concrete policy difference across the four states, namely legislation on language instruction at school. Do such policy differences with a direct effect on the migrants translate into differences in the sense of belonging which migrants remit back home through their letters? Policies on language instruction at school still exist (Hornberger 2002: 4646), unlike the much harsher integration policies following World War I (Krawatzek and Sasse 2018a).

\footnotetext{
${ }^{1}$ The authors are grateful for research assistance provided by Christian Fastenrath and Hannah Vögele. The article is based on research facilitated by the Large Leverhulme Trust Grant "Political Remittances: Understanding the Political Impacts of Migration” (M3RVQL00), and a Small Award from the John Fell Fund/Oxford University Press Research Fund (143/003).
} 
The first section briefly discusses the importance of destination characteristics for migrants' transnational belonging. We then provide an overview of our corpus of letters written by ordinary German migrants in the US and introduce the paired comparison of two states with more open vs. two states with more restrictive policy regimes on language instruction as well as our combination of quantitative and qualitative text analysis. The final section discusses our results. We find that subnational policy variation on language policy is less consequential in the personal narratives of belonging than could be expected. Local contexts matter, but primarily in terms of framing the migrants' strategies and embedding them in social networks. The widespread descriptions of bilingual everyday practice remit a transformative idea of participation and belonging to the recipients of the letters.

\section{Local conditions and the sense of belonging}

A significant body of scholarship has investigated national immigration regimes and contributed to our understanding of how differences in the immigration policies of nation states impact the integration and sense of belonging of migrants (Brubaker 1992, Favell 1998, Joppke and Morawska 2003). This latent methodological nationalism (Glick Schiller and Çağlar 2009, Wimmer and Glick Schiller 2002) has downplayed the significant sub-national and within-group differences in how migrants experience their integration into their respective host societies and how they continue to feel connected to their places of origin. Our focus is on the migrants' communication of an intersubjective and hybrid sense of belonging rather than an assessment of structural measures of integration. This sense of belonging is continuously shaped by the migrants' environment from the moment they arrive in their new locations (Krawatzek and Müller-Funk this issue). It captures a fundamental change in the migrants' everyday lives and identities and has a potentially transformative impact on the perceptions of the recipients of the letters.

The study of particular localities through archival sources or ethnographic research lends itself to exposing the diversity of migration trajectories. Historical studies have provided, for example, detailed accounts of the conditions of German-speaking migrants in Philadelphia (Kazal 2004), Germans of Russian descent in Oklahoma (Hale 1980), Westphalians in Missouri (Kamphoefner 1987) or transatlantic migration from Mecklenburg (Werz and Nuthmann 2004). However, we lack a comparative 
basis from which to assess the extent to which local conditions affected narratives of belonging within migrant groups.

German-speaking migrants in the US were an extremely diverse group in terms of religion (Lutherans, Catholics, Jews, and Atheists), economic status, education as well as political outlook (Gabaccia et al. 2007: 6565). This diversity in part results from the fact that for most of the $19^{\text {th }}$ century there was no integrated German state. German migration therefore resembles the Italian case for which Gabaccia illustrates that the lack of a common culture, language and government meant that regional identities trumped unifying conceptions of nationhood (2000). Similar to the Italian case, German-speaking migrants developed a sense of belonging to a German nation also through the experience of migration which in the case of Germany accelerated after the unification of 1871. Prior to 1871, German-speaking migrants nevertheless shared an interest in preserving their language and customs through extensive social networks.

The bigger question behind our analysis that leverages sub-national policy variation is the extent to which a state affects the narratives of belonging to places of origin and destination, and thereby the integration of its migrant stock. Comparing how integration narratives transmitted by members of one migrant group, however loosely defined, vary within a given country keeps important national aspects constant, such as, the overarching political system, foreign policy orientation, macro-economic policies, etc..

Throughout the $19^{\text {th }}$ century, emerging nation-states attempted to integrate the various group identities encountered in their state boundaries (Weber 1977). In the case of Germany this included the active mobilisation of Germans abroad to expand the reach of the nation (Manz 2014). But this phenomenon was not limited to Europe as Takenaka's study of Japan's relationship to its overseas population illustrates (Takenaka this issue). However, despite the enormous resources that states have mobilised, the outcomes remained incomplete. A closer look at variation between more open and more restrictive policies in a historical context puts contemporary issues in a broader perspective. It speaks to the time horizons involved in processes of integration and the more recent emphasis on the evolution of migration trajectories over time (Waldinger and Green 2016). 
In social science research, a more systematic exploration of whether and how different destination characteristics affect migrant transnational engagement has also only recently become a more systematic focus. Sociologists and anthropologists have, for example, explored the dynamics of diversity in cities (Glick Schiller and Çağlar 2009), and political scientists have started to analyse the role of local actors and institutions comparatively (de Graauw and Vermeulen 2016). Generally, migrants in highimmigrant concentration areas are seen as more likely to engage in homeland politics (Levitt 2001), including in homeland elections (Baubock 2003: 714714).

This paper builds on nascent efforts in various social science sub-fields to understand the role of national and local destination characteristics by leveraging the wide geographical dispersion of the German migrants in the US and the significant policy and legislative diversity in the US at the time. We focus on language policies and hypothesise that policies limiting or enabling the public use of the migrants' native language affects their sense of belonging and the image they convey of the society they live in.

\section{Migrant Letters: An overview of the data}

The letter collection at our disposal is stored in hard copy at the Forschungsbibliothek Gotha in Germany. ${ }^{2}$ The letters exist as transcribed versions of the hand-written letters, albeit in a format that cannot easily be turned into machine-readable documents (because of thin old paper, fainted ink, numerous hand-written remarks, typographical inconsistencies, irregular fonts). We have scanned or photographed the entire collection of letters to enable the complete digitisation and make this corpus machine-readable. We have transferred the letters into one database and have collected all available (though limited) metdata about the writers, including information about their profession, marital status, date of birth, financial situation, and reasons for emigrating. When completed, this dataset will complement large collections of already digitised Irish letters which are mainly based on Miller's collection (2003), see CORIECOR (McCafferty and Amador-Moreno 2012). Valuable overview

\footnotetext{
${ }^{2}$ It has been compiled for over more than 30 years from across German-speaking Europe by Wolfgang Helbich, Walter Kamphoefner and Ursula Lehmkuhl. We are grateful to Ursula Lehmkuhl and the staff at the Forschungsbibliothek Gotha, in particular Monika Hasenmüller, for the help provided to access the documents. The complete dataset will be publically available at https://doi.org/10.6084/m9.figshare.4516772. The letters are abbreviated as follows: a first letter indicates the first letter of the name of the series as stored in the archive, the following three numbers are a number for the series and the last three numbers refer to the number of the letter in that series.
} 
editions and publications focusing on particular themes in the letters have resulted from the German collection (Helbich 1987, Helbich 1988, Helbich and Kamphoefner 2004, Helbich et al. 1988).

The migrants in our corpus were typically of a lower social status, reflecting the overall pattern of German-US migration. Their professional profile is diverse and ranges from farm labourers (Tagelöhner) and migrants who had studied law in Germany and found themselves working as a lumberjack (Holzarbeiter), to craftsmen and professionals who had language skills and worked in offices or shops. The financial position of the migrants represented in the corpus varies as much as their professional profiles. While some never achieved financial independence in the US and had to rely on financial transfers from their family in Germany throughout their lives, others enjoyed economic success and could help their family back home financially.. Migrants also tried to incentivise their family to send money by providing sometimes overly optimistic descriptions of economic opportunities in America and thereby offering to relatives and friends the opportunity to invest money overseas.

We focus on four states (Illinois, Wisconsin, Ohio and Missouri) that are similar in terms of basic characteristics, such as urban and rural composition and the overall density of German migrants. Ohio and Wisconsin included large urban centres with very high shares of German migrants (e.g. Cincinnati and Milwaukee respectively, up to $20 \%$ during the $19^{\text {th }}$ century); Missouri and Illinois were urban centres with medium shares of German settlers (e.g. St. Louis and Chicago, around 10-15\% during the $19^{\text {th }}$ century). In terms of their socio-economic and financial profiles, the letter writers in the four states under scrutiny correspond to the overall variation in the corpus. It is therefore unlikely that potentially confounding differences in terms of political outlook or their sense of belonging prior to migration explain the patterns across the four states. However, given the limited information about the letter writers in this historical collection, it is not possible to make a firm statement about the composition of the sample in that regard. Previous research by Helbich and Kamphöfner also suggested that this corpus is largely representative of the overall profile of German migrants (2006).

The four states also cover a sizeable share of the overall letters in the corpus both in terms of the total number of letters as well as the total number of overall words (Figure 1). 
In terms of their temporal distribution, the letters span the entire wave of German-US migration, taking off rapidly in the first half of the $19^{\text {th }}$ century and staying at a relatively high level until the turn of the century. Emigration levels drop around 1900 and with it the frequency of letters, before increasing again somewhat in the interwar period. The four states at the centre of our analysis correspond to the overall distribution of letters in the corpus, peaking in the 1860s and the 1890s and then again in the interwar period.

The letter writers tended to be in touch for an average of just over 18 years with great variation around the mean ( $\mathrm{SD}=20$ years). There is thus no unique pattern; instead, some writers were engaged in the transatlantic exchange for decades, whereas in other cases the migrants only wrote letters for a short while.

\section{Research Design: Variation in language policies}

The letters raise the issue of schooling including considerations on language teaching which directly impacted on the migrants' lives. Already the first German settlers in the $18^{\text {th }}$ century founded German schools. Education was closely connected to widespread concerns about "losing one’s German culture”. The letter writers describe the educational styles of different confessions or the challenge of multilingualism which resulted from being surrounded by different European languages (H006_007, S030_007). Especially in rural areas migrants set up schools linked to the local churches (S001_029. S001_077, S030_007, E009_068, G011_041, N003_014). Having a good German school was something that was reported with pride in the letters and served to reassure family members back home (S001_100, B109_010, M012_005). The educational system is thus an integral part of the institutionalised hybrid identities of migrants which often also have a political salience, as Anderson's case study on the Danish speaking migrants in America highlights (this issue). The language policy regime in place can therefore be expected to impact the degree to which migrants could maintain their identity between 'here' and ‘there'. 
The letters do not allow us to explore systematically whether policy differences between the states played a role in migrants' choices as to where to settle. Although transatlantic migrant networks underpinned chain migration, we cannot find evidence that the issue of schooling is brought up when the decision to migrate is being discussed. It seems therefore unlikely that migrants clustered in one place because of school provisions.

We have collected data about restrictions on language teaching across the United States for the period between the 1830s and 1920s. ${ }^{3}$ We coded the type of school targeted by the legislation (public and/or private), the target language of the policy, the type of provisions, and the school subjects to which regulations applied. We found legislation on the teaching of foreign languages as well as on the language of instruction overall in every state, except for Alaska, Florida, and Hawaii. On the basis of this data, we drew up our paired comparison: Wisconsin and Illinois represent states with restrictive language policy regimes, while Missouri and Ohio are two states with more open policies in place.

\section{a. Restrictive policies: Wisconsin and Illinois}

Wisconsin initially allowed instruction in foreign languages and German models of education had great influence. The teaching in German became curtailed by the stringent state school law of 1869 which limited foreign-language instructions in all state schools to one hour per day. The "Bennett School Law" of 1889 specifically targeted Germans required children to be taught all basic subjects in English, including in parochial schools (Catholic and Lutheran). Thereby, English became the only language of instruction for most subjects in non-state schools. The law was repealed in 1893, but teaching in English became mandatory again in 1903. During World War I, the law stipulated that the teaching of foreign languages in general was prohibited in state schools, with a possibility of teaching a maximum of one hour per week on exceptional grounds.

Illinois initially allowed schooling to be in foreign languages and legally recognised this principle by 1857. A law passed in 1872 continued to permit foreign language instruction in cases where the School Board or the voters of the district made an explicit request to this effect. However, the "Edwards Law"

\footnotetext{
${ }^{3}$ We consulted the following sources: (Baron 1990, Capozzola 2008, Fitz-Gerald 1918, Flanders 1925, Handschin 1913, Kellogg 1918, Kloss 1966, Pavlenko 2002, Ramsey 2012, Schlossman 1983, Tolzmann 1994, Tolzmann 2006, Zeydel 1964).
} 
of 1889 specified that English had to be the language of instruction in state and non-state schools. The law caused significant debate and was repealed in 1893 after which greater flexibility returned. This accommodating approach came to an in the run up to World War I.

The pattern in both cases is one where migrants briefly had the opportunity in the early $19^{\text {th }}$ century, under conditions of low state-regulation, to access schooling in their own language. However, in both states the public mood and policies towards German migrants in particular turned and eradicated traces of the more accommodating policies of the middle of the $19^{\text {th }}$ century. One contemporary observer compares the two laws of 1889 to a declaration of war: "Why all at once this war on the Germans here in Wisconsin as well as in Illinois? For the Bennett Law indeed means war.” (Kellogg 1918: 1919).

\section{b. Permissive Policies: Missouri and Ohio}

In the early $19^{\text {th }}$ century migrant communities were free to organise their schooling independently. We see in the letters that the German community in rural Missouri tended to have instruction in both German and English in both public and private schools. The public school system expanded rapidly under the leadership of the educator William T. Harris, and by 1870, German-language teaching as part of a bilingual education system was common in public schools as well as in almost 100 private schools in the city of St. Louis alone. Roughly half of all children of German descent in St. Louis were taught in German only. One state superintendent even lamented in 1880 that "in a large number of districts of the State the German element preponderates, and as a consequence the schools are mainly taught in the German language” (quoted in Ramsey (2012: 6363)). However, our corpus of letters underlines that despite Missouri’s liberal setting, the situation was not without its ambiguities. Discussions amongst legislators in 1879 to limit German language teaching in St. Louis caused anxiety amongst the migrants. The more than 40000 signatures on a petition against proposed legislation testify to the fact that the language of instruction at school was important to the migrant communities (Kamphoefner 2003: 949694-96). The more restrictive approach introduced in Illinois and Wisconsin in the 1890s caused concerns amongst German-speakers in Missouri who responded by intensifying their political lobbying. 
In Ohio, the approach to the language of school instruction was initially permissive or even encouraging. In 1837, it was stipulated that classes ought to be taught in German wherever 75 citizens requested it for at least 40 pupils. The 1839 Hoosier Law legalised the utilisation of foreign languages in all schools. Thereby, Ohio became the first Midwestern state to provide for the teaching in German which alleviated the financial burden of the settlers who had previously paid for private tuition. Cincinnati's elementary grades introduced teaching in German in 1840, and a statute in 1842 stipulated that pupils could switch to a German language school in a different district upon the parents’ request. Ohio’s legislation remained permissive throughout the $19^{\text {th }}$ century. German-English bilingual schools had come to exist widely around 1840, and migrants wrote with pride about their children's multilingualism or that of their friends (S001_076, B114_002). German teachers also organised institutionally by setting up the "Deutsche Lehrer-Verein” [German Teachers' Association] in 1889, which was aimed at supporting bilingual education and the preservation of German culture. German language instruction remained available and it was a legal requirement that a number of subjects were taught in German in public schools until 1903.

In the run-up to World War I, legislation became slightly more restrictive but remained comparatively accommodating in both states. In 1915, there were 175 teachers of German in Cincinnati alone. Subjects could be taught in German alongside English. However, the anti-German public mood of World War I led to a drop in enrolment numbers. ${ }^{4}$ The 1923 statute of Ohio provided that the German language should not be taught before eighth grade in any school.

\section{Empirical strategy}

We combine qualitative and quantitative methods of text analysis to gain a better understanding of differences and similarities reported in the letters sent back across the Atlantic. We focus on education, the preservation of the German language in the US, the learning of English and, most importantly, the link between language practices and the extent to which migrants expressed a sense of belonging to the

\footnotetext{
${ }^{4}$ Along similar lines, Pennsylvania had an open language policy at the beginning of the $19^{\text {th }}$ century which remained in place until the late $19^{\text {th }}$ century. The earliest German-speaking American settlers of the $18^{\text {th }}$ century set up schools in their mother tongue. In 1837 a law was passed which put German schools on an equal footing with English ones - in some schools, the only language of instruction was German.
} 
US and/or Germany. We first analyse patterns in the letters by state using collocations and concordances. The initial focus is on words related to language policies, such as "German”, "English”, "school” and terms indicating belonging such as "Heimat". We examine the linguistic context of those terms to gain a better understanding of their use, following research that has shown the analytical value of applying corpus linguistics to migrant letters (Avila-Ledesma and Amador-Moreno 2016, Moreton 2012). We supplement this analysis with a focus on two migrant families chosen to illustrate different but typical trajectories on the basis of detailed information generated by the keyword in context approach applied to the two letter series.

\section{Discussion of Findings}

\section{a. Schooling and language of belonging: between the transnational and the local}

If sub-national cultural immigration policies influence the ideas of belonging that migrants remit back to their families and friends in Europe in the form of political vocabulary and their local practices, we would expect to detect differences in the language patterns in the letters across the two pairs of states. Most importantly, we would expect to find patterns concerning the use of words related to education. Considering the importance of teaching-related words, there is an overall higher frequency per 100 terms of UNTERRICHTET [teaches/taught] and UNTERRICHT [teaching or class] in the two states with a more permissive policy setting compared to the average use within the overall corpus and the two states with a more restrictive policy regime (Figure 2). Whilst these terms refer mostly to the process of teaching, the terms GELERNT and LERNT [learned/learning] instead emphasise the actual acquisition of knowledge. The latter two terms are most prevalent in letters from Illinois, one of the states with a more restrictive language policy regime. Looking in more detail at how the term is used, migrants wrote about their accomplishments, such as learning a foreign language, which distinguishes them from their friends and relatives in Europe who lacked comparable opportunities. Therefore, the restrictive policy setting that migrants encountered in Illinois was not something that they picked up in the letters, instead they emphasised the process of English language acquisition and thereby, a heightened sense of belonging linked to the United States. 
Figure 2: words related to schooling

In a next step, we analysed the meaning of these school and education related terms by computing their collocations and by looking at the use of these terms in their context. A closer analysis of the language used by the letter writers to discuss educational matters in the states with a more restrictive policy suggests that rather than complaining about these language policies, the migrants took issue with restrictions on the teaching of religion at school that was enacted at the time (Table 1, A103_003). One exception among the letter writers was Johann Spannagel who contemplated moving to St. Louis to ensure the German language education of his son and who valued the German newspapers in Missouri (Table 1, E005_019). Migrants in the two states with a restrictive language policy setting tended to write with a sense of enthusiasm about the fact that education was free and of high quality (Table 1, T005_042, W007_011). Those who wrote about learning English did not convey value judgements alongside their descriptions of how they became more familiar with the English language (Table 1, S033_009). The impression is one of appreciation for access to free schooling in general, the pride in reporting progress in learning English, and a realistic assessment of the need to learn English as a part of everyday life (Table 1, G009_030). These signs of integration into American society do not contradict the active attempts to preserve emotional bonds in the places of origin. Writing the letters and discussing one's own sense of identity - here filtered through the experience in a new language environment - contributed to the evolution of a hybrid identity as German-Americans.

Table 1: Selection of concordances Illinois and Wisconsin

In the two states with more permissive language policies (Missouri and Ohio), the analysis of the use of school related terms similarly conveys that migrants, despite the fact that schooling could have continued in German, appreciated their emerging bi- or multilingualism (Table 2, H021_008). Teaching- 
related statements underline the value of having free education for young children and migrants, a reality of life in the US they report with astonishment. Some of the political debates around education find their way into the letters (Table 2, S001_140), for example concerns about the state of “republican education” in the US (Table 2, S030_005). The reality of granting access to schooling brought with it the challenge that it was often difficult to find competent staff able to teach a class of German- and English-speaking children (Table 2, S030_010). As a result, the level of teaching in German was often said to be low and children seemed to intuitively switch to English as their social language (Table 2, S001_093). We also find explicit links between the abstract value of education and the value of democracy (Table 2, S030_010). ${ }^{5}$ The migrants write about their involvement in teaching English to newly arrived fellow Germans (Table 2, S030_004, B110_006), and also highlight that some migrants carefully prepared for emigration by learning basic English before their arrival in the US (Table 2, S001_046).

Table 2: Selection of concordances Missouri and Ohio

In both sets of states, migrants emphasise the need to learn English upon arrival whilst also affirming that they did not see this as a great burden. Strikingly, also in Missouri and Ohio where schooling could be in German, migrants wrote about the inevitability of learning English at school. The letters articulate questions of language acquisition or preservation and schooling more generally alongside notions of belonging. A telling example is Johann Schipper who wrote back to his father upon his arrival in Pekin, Illinois, in 1865. He explicitly connected his English language knowledge with feeling at home in the US. He reports that he has already got used to life in the US and that he definitely would not want to exchange his current place of residence for his former homeland once he has mastered the English language. ${ }^{6}$

\footnotetext{
${ }^{5}$ For idealistic visions on politics in particular among early migrants see (Krawatzek and Sasse 2018c).

6 "Das hiesige Leben ist mir schon so ziemlich zur Gewohnheit und wenn ich erst Englisch spreche, glaube ich um keinen Preis mit meiner früheren Heimat zu tauschen, jetzt meine ich selbstredend Amerika meine zweite Heimath.” (A103_001).
} 
Even newly arrived migrants thereby remitted a hybrid sense of identity to their families and friends, emphasising their belonging to both places. Indeed, in 1896 a family in Ohio emphasises in a letter that despite their children being taught in German at school, the younger generation had almost forgotten it and were much more competent in English by now. This contextualisation suggests similarities in how terms relating to English language teaching and the use of German across the four states appear in the letters, irrespective of the different state language policies. Instead, the practice of speaking German or maintaining social ties among Germans continued under both conditions, as did the realisation that one had to learn English. Both ideas were "sent back" to Europe via the letters, which in turn is likely to have shaped ideas about identity and education amongst the recipients.

The context in which terms such as HEIMAT [home/homeland] and VATERLAND [fatherland] are used further highlights that speaking English was an important underpinning of a feeling of belonging (Krawatzek and Sasse 2018c). HEIMAT and VATERLAND are used on average twice as frequently in the letters from Wisconsin and Illinois, the two states with the more restrictive approach to language use, as in the rest of the corpus. However, beyond this difference in frequency, an analysis of the collocations with HEIMAT suggest no clear patterns by state but rather an impression of the corpus overall (Table 3). Two important clusters of usage cutting across states can be identified, echoing a finding from the analysis of Irish migrant letters: "From a corpus linguistic point of view, home and country stand as the most frequent and highly salient terms for men and women in the sphere of diasporic identity making.” (Avila-Ledesma and Amador-Moreno 2016: 93-4, 10293-4, 102). First, HEIMAT is the place left behind, and the writers either express a sense of distance or longing. They write about ALT HEIMAT [old homeland], comment about receiving or asking for news VON ALT HEIMAT [from the old homeland] and inquire about the lives of their friends and relatives IN ALT HEIMAT [in the old homeland]. Words such as "beloved”, "good” or "precious” precede these expressions and illustrate the persistent emotional link with the place left behind which was reactivated by the letter exchanges. Writers ask for letters from the "beloved home” (S010_003) or the "dear old home” (R001_002) or bemoan their distance from "the precious home” (K002_006). The combination of HEIMAT VERLASS [leaving the homeland] also conveys a sense of this emotional linkage. Second, however, HEIMAT could also convey a sense of already having integrated in the new place. SEIN [his], IHR [her] or MEIN [my] HEIMAT tend to be used 
when migrants affirm their new place of residence as being the place they emotionally and practically identified with (K019_021, A105_003, F008_006). The letter writers mention that they were going to create their new homeland or that they preferred their new homeland to Germany. These two sets of meanings, longing for the old or embracing the new HEIMAT emerging from the collocations are also used simultaneously by writers, which suggests that integration in the US and the maintenance of transnational emotional networks co-existed.

Table 3: Collocations with HEIMAT

The corpus linguistic perspective on the use of terms relating to schooling as well as the sense of belonging does not point to a clear pattern by state or language policy regime. The letters suggest that the state level is not a strong indicator for understanding the meaning of terms related to belonging which the migrants remitted to Europe via their letters. Contrary to what could be expected in light of the clear policy differences across those states, the hybrid identity which migrants develop and transmit can be encountered in both contexts.

\section{b. State restrictions and locality}

This following section identifies different integration trajectories derived from an in-depth qualitative analysis of two letter series and the narratives of belonging they contain. These differing trajectories one from Missouri and one from Illinois - provide insights into the ways in which migrant families dealt with the (non-)availability of school instruction in German and their strategies to adjust to the local conditions and how they communicated these experiences to their loved ones. The migrants adapted to the changing policies over time by adopting compensatory mechanisms when policies shifted - or were likely to shift. In the more permissive settings, the value attached to bilingualism remained high and migrant families found ways to use the German language beyond the school context. In the more restrictive settings, the practice of gathering within German circles continued, although the practice of 
speaking German diminished. The integration narratives that migrants remit back to their families and friends are thus strongly informed by the locality in which they lived and the corresponding social networks rather than the cultural immigration policies emanating from the state level (Krawatzek and Müller-Funk this issue).

\section{i. $\quad$ Two contrasting German-American trajectories}

We focus on two representative families to explore different integration trajectories and reactions to actual policy shifts or threats of policy shifts in two of our four states. The writers behind the selected letter series differ in their educational background and, it can be assumed, their level of political awareness and responsiveness to differences in local political conditions. In both cases, we selected families which wrote from rural America where close German-speaking networks persisted. This choice ensures a higher degree of similarity between the migrants' experiences.

Jette Bruns Geisberg, a housewife from rural Germany, wrote most of the letters in the Bruns-Geisberg series. The Bruns-Geisberg family - the physician Dr Bernhard Bruns, Henriette (Jette) Geisberg, their two-year old son and Jette’s brothers Franz and Bernhard - left Germany in 1836 and settled with numerous other Germans in the settlement Westphalia in rural Missouri. Dr Bruns, as Jette referred to him, succeeded in setting up his medical practice with financial success (S001_024; S001_046), but over time, the everyday reality of life in America diverged from the general positive idea of America prevalent in Germany. Their house remained in poor condition, winters were severe, spring frequently brought floods, and summers tended to be dry and the meagre crops meant that there was very little to eat. Moreover, of the ten children born in America, five died in childhood.

The collected letters of the Bruns-Geisberg family cover the period from 1828 to 1899 and therefore lie above the average length of letter exchanges in the overall corpus. Close to three letters are written per calendar year in this series on average, illustrating the intensity of this family's transnational communication. Jette wrote primarily to her family in Münster, in particular to her brother Heinrich, her 
uncle Casper Geisberg and her sister-in-law Auguste. Moreover, the collection contains some letters Heinrich wrote to Jette, and letters sent to Germany by Jette’s husband and her brother Franz.

Our second case study, the series Matthies-Matthies, spans the 1880s-1920 and provides insights into both local language practices and the integration experience more generally. Heinrich Matthies, who started signing off as "Henry" shortly after his arrival in the US, arrived via Bremen and Baltimore in Chicago in 1871. He writes individually addressed letters to various family members in and around Magdeburg, including his brother, Wilhelm Matthies, his sister-in-law Auguste, his mother in Hohendodelben near Magdeburg and his nephew.

The two series do not differ significantly in their linguistic diversity. Nevertheless, the respective educational backgrounds can be gleaned from the type/token ratio (TTR) which is a good indicator of lexical diversity (Figure 3). ${ }^{7}$ The Bruns-Geisberg letters display a more complex language than other letters of a similar average length per letter. The Matthies-Matthies letters are on average slightly shorter than those in the Bruns-Geisberg series and their level of linguistic complexity, as conveyed by the TTR, is closer to the corpus average.

Figure 4: Type-Token Ratio Bruns-Geisberg (MO) (square) and Matthies-Matthies (IL) (triangle) compared to overall corpus

\section{ii. $\quad$ Bruns-Geisberg Family in Missouri: bilingualism and transnational belonging}

The letters from Missouri highlight the importance of schooling and education policies for the family's narrative of belonging sent across the Atlantic. Dr Bruns himself got involved in the construction of a “female academie” (S001_100) and there are numerous references to the children’s schooling but also to the adults' free access to evening schools (S001_135, S001_102). Notwithstanding the readily available German networks in the village of Westphalia in the early $19^{\text {th }}$ century, the letters emphasise

\footnotetext{
${ }^{7}$ For instance, if a writer of a letter consisting of 100 tokens, the total number of words, and uses 90 different types, the unique terms, her TTR $=.9$. If, however, she uses little variation and repeats similar words, her TTR would be lower. We would expect TTR to drop as a function of length - the longer a text the higher the chance of repeating certain words such as grammar words or set phrases.
} 
that all family members were learning English (S001_012, S001_023, S001_035, S001_058) and proudly report the progress they were making. English language knowledge helped Jette, for instance, to assist her husband in the medical practice and thus facilitated a sense of economic integration. In the absence of political constraints or obligatory exclusive English-language school instruction, this migrant family clearly felt the need to get accustomed with the local language and devoted resources to doing so upon their arrival in the US.

Bruns-Geisberg's children and those in their neighbourhood learned English and German. However, the letters report that English, even for the children of Westphalia, became the natural choice although the parents highly praised the bilingual teaching available in larger settlements (S001_099). ${ }^{8}$ Those teachers who spoke English and German were held in high regard (S001_100). Nevertheless, maintaining the level of German among the second generation, even in the accommodating setting of Missouri, proved difficult. Writing to his uncle, Franz stated that his offspring spoke primarily English with one another, something he also linked to the fact that the teaching in German was usually "mangelhaft" [poor]. However, writing in 1856, his description of the extensive immersion into English was not characterised by regret (S001_093).

Political debates in 1878 and 1879 about ending German-language schooling in public schools in St. Louis are mentioned in the letters (S001_140, S001_144). In March 1878 for example, Irish migrants opposed the continuation of teaching German in public schools in Missouri's capital and put forward a petition asking for the introduction of Gaelic. A counterpetition by the German community, signed by 40,000 people, called for maintaining the existing system. When a municipal ban of German language schooling was introduced, the implications became clear when Jette's daughter found herself unemployed (S001_173) and forced to seek employment in the private sector. By 1881, the frustration about the obligation to teach in English in St. Louis, notwithstanding a lack of English language knowledge on the part of the teachers, is expressed in the letters alongside a sense of feeling distant from American life in general (S001_150). As it became more difficult to preserve the German language through the school system, the Bruns-Geisberg family started to seek alternative ways to keep its

\footnotetext{
${ }^{8}$ Den Kleinsten, Heinrich, habe ich hier zu einer deutsch-englischen Schule gegeben, auf daß er regelmäßigen Unterricht genießt, den er auf dem Lande nie gehabt hätte.
} 
German heritage alive. For example, the letters contain evidence of the children getting private tuition in German to counterbalance the prevailing instruction in English (S001_173).

The letters of the Bruns-Geisberg family highlight the readiness with which its individual members stepped into American life and actively attempted to adjust culturally by learning English. The letters remit political principles, when the writers elaborate on the political setting they are embedded in, and a multi-layered idea and vocabulary of belonging when language practice and the value of bilingualism are spelled out. Indeed, in the absence of far-reaching state involvement, this family of migrants participated in its rural community in both English and German and also showed interest in the political affairs of their locality. They wrote about political developments in their letters, including their growing frustration regarding the restrictions placed on the teaching of German in public schools in St. Louis. Maintaining bilingualism and thus a tangible link to Germany was important to many of the writers, and the dense German networks in Missouri partly compensated for the restrictions put upon the migrants by the state.

\section{iii. Matthies-Matthies in Illinois: German networks and transnational belonging}

In early November 1905, Henry Matthies elaborated in detail about his tightly knit community in rural Illinois. This German-American neighbourhood had a social function - the second generation still prevailingly married within this local neighbourhood. (M001_004) - and its networks offered economic security (M001_004). ${ }^{9}$ However, these letters testify to the difficulty of maintaining a transatlantic network of communication. Henry expressed concern about not receiving answers from his family and friends in Germany (M001_006). Although the frequency of exchanging letters had dropped by the 1920s these transatlantic networks continued to channel American money back to Germany (M001_008), particularly in moments of economic crisis: “a lot is being sent to Germany” Henry commented (M001_010). The migrants preserved or reactivated close personal transnational links in a

\footnotetext{
${ }^{9}$ A more extensive analysis of the role of German-American and transatlantic networks can be found in (Krawatzek and Sasse 2018b).
} 
climate of economic uncertainty, pointing to the compound nature of remittances (Krawatzek and Müller-Funk this issue).

Henry also noted occasionally that he was the only one left who could still write in German - his children and grandchildren had been completely anglicised through school (M001_008). The fact that Germanlanguage competence had remarkably decreased in Illinois, however, did not mean that migrants had stopped valuing and practising German customs or attending German community gatherings. For instance, Henry highlighted in 1921 that he had taken part in the celebration of the $100^{\text {th }}$ birthday of Bauer, a local farmer. More than 100 people came to celebrate and, as Henry notes, mostly arrived by car - a reference to a higher level of mobility and more disparate settlement patterns. This example indicates the persistent social ties within the German-American community and Henry, in that same letter, emphasised that in general "people help out one another" (M001_010). Old village and neighbourhood ties, at least some of which were still shaped by the initial German migrant settlement patterns, fulfilled an important social function even in the interwar period. For example, when Henry had to move, he found a room in the house of "an old German lady" called Frau Fick (M001_023).

In terms of language practice, letters from Illinois frequently highlight the need to learn English in order to succeed. Henry reported with pride that he "naturally" handled all correspondence in English, not least to educate himself in matters related to agriculture and the smooth running of his farm (M001_012). Notwithstanding the fact that German language gradually lost its place as the primary language of communication in the community, Henry underlined that he was always very pleased to meet all the other old farmers in the German Methodist church and pointed to the existence of a local German Lutheran church (M001_024) as late as 1921. Despite his strong narrative of belonging tied to his place of residence, Henry continued until his death to engage in extensive political commentary on Germany in his letters (M001_021, M001_027). Although the state policy affected the prevalence of spoken German in this community, its effects on the local practices of German gatherings were limited.

Other migrants in Illinois also reported positively about the availability of cheap or free English language classes (S021_010). The classes were even seen as a German community gathering when entire neighbourhood circles attended (S033_005). There was no mention of state pressure to learn English, 
and we found no complaints about the lack of opportunities to speak German. Irrespective of whether recently arrived farmers, farm labourers or young women working as maids wrote the letters, they convey the impression that those settling in Illinois did not question the state policy regime but either tacitly accepted or actively embraced it. In their letters, they proudly reported about their own progress in learning English and that of their relatives and friends (S034_013). The gradually more restrictive policies during the late $19^{\text {th }}$ and early $20^{\text {th }}$ century did not mark a significant rupture in the letter writers' perception and their sense of belonging to both the places of origin and destination. Continuity rather than change characterised even the letters from the World War I and interwar periods.

The picture that emerges from these letters is one of a simultaneity of integrating into American life through English language acquisition on the one hand - through evening classes and in the case of his children already a full immersion into an English-language school system - and maintaining transnational family links and staying within a local German-American community. Rather than contradicting one another, these different dimensions of belonging, navigating and connecting the local and the transnational, seem to reinforce each other.

Our closer look at individual letter series highlights similarities in the migrants' experiences, compensatory strategies and narratives of belonging irrespective of the difference in the overarching state language policies. At the individual level and in particular local contexts, it becomes obvious that learning English and the idea of bilingualism were prominent in both policy settings. The need to engage in compensatory strategies, for example through private German tuition or mixing in German social networks, differs temporally, thereby reflecting the varying speed with which more restrictive language policies were adopted across the two states rather than a difference in substance or the resulting narratives of belonging.

\section{Conclusion}

The aim of this article was to explore if and how sub-national variation in destination characteristics is expressed in the narratives of belonging by German-speaking migrants in America. We approached this 
topic by leveraging variation in the policy regimes related to schooling in a foreign language until the interwar period. We hypothesised that such policy differences influence the migrants' sense of belonging to their place of origin on the one hand and their place of residence on the other and looked for patterns in the corpus and differences between letters across the two sets of states.

However, our text analysis has not revealed a systematic difference across the two types of states with different policy approaches. Our analysis suggests that migrants tend to be less responsive to their policy environments than policy-makers might think. Though placed within a different empirical context, our findings point in the same direction as Joppke’s claim that it might be futile to try to further identity through state policy (2012: 135135). ${ }^{10}$

Our more detailed look at individual letter series spells out these dynamics in more detail, suggesting an early acceptance of the greater state emphasis on learning English where it existed - through evening classes and English-language schools. Although this state-policy encouraged an earlier move towards English language proficiency, bilingualism and a shift to English as the dominant language from the second generation onwards, this process did not go hand in hand with a loss of local German neighbourhood ties, traditions and transnational family linkages. It rather seems that the two processes reinforced each other. Our research supports the claim that integration is not a process where migrants “discard one political identity for another” (Waldinger and Feliciano 2004: 8-98-9). Moreover, migrants did not complain about the need to learn English but rather endorsed it. With or without explicit state policy, the migrants themselves recognise the advantages of learning the language of the host country, while also valuing bilingualism and maintaining German customs and social networks.

Writing in a letter addressed to family members or friends in Europe about one's choice to maintain (or not) the German language and community ties is part of the political vocabulary and the political practices that migrants remit. Jointly, they form a narrative of transnational belonging while also offering those who stayed in the places of origin their own new vocabulary to think about identity. Practicing one's culture in the host society is also a political choice as this case study illustrates since such a

\footnotetext{
${ }^{10}$ Similarly, Brubaker underlines that integration is something “accomplished by" and not "done to" people which further limits what the state can accomplish in that regard (2003: 51-5351-53).
} 
decision might challenge the state's existing integration policy. However, what the letters reveal is that local conditions are relevant for transnational belonging, most visibly in the form and density of migrant social networks. However, sub-national variation in a prominent case of cultural immigration policies is not. In this paper we have been dealing with one historical group of migrants and one policy distinction. On this basis generalisations are impossible, but the findings at least caution us against a clear-cut causal link between certain cultural immigration policies on the one hand and migrant strategies and perceptions of belonging on the other hand. Moreover, the focus on the reflections of a large number of 'ordinary’ migrants highlights the importance of tracing their perceptions of belonging in addition to measuring the migrants' integration based on objectified criteria. The migrants themselves are clearly transformed in their outlook on life, and they consider it important to communicate their lived experience in between cultures and places alongside the vocabulary, ideas and identities that go with it through their letters. In turn, these political remittances have the potential to have a transformative effect on the worldview of those who stayed behind. 


\section{Bibliography}

Anderson, lain. (this issue). "We're Coming!" Danish American Identity, Fraternity, and Political Remittances in the Era of World War Two. Journal of Ethnic and Migration Studies.

Avila-Ledesma, Nancy E \& Amador-Moreno, Carolina P. (2016). "The More Please [Places] I See the More I Think of Home": On Gendered Discourse of Irishness and Migration Experiences. Yearbook of Corpus Linguistics and Pragmatics 2016, pp. 85-105. Springer.

Baron, Dennis (1990). The English-Only Question: An official language for Americans?, New Haven: Yale University Press.

Baubock, Rainer. (2003). Towards a Political Theory of Migrant Transnationalism. International Migration Review, 37:3, pp. 700-23.

Brubaker, Rogers. (1992). Citizenship and Nationhood in France and Germany, Cambridge, MA: Harvard University Press.

- - . (2003). The Return of Assimilation? In: Joppke, C. \& Morawska, E. (eds.) Toward Assimilation and Citizenship, pp. 39-58. Basingstoke: Palgrave.

Capozzola, Christopher Joseph Nicodemus. (2008). Uncle Sam Wants You: World War I and the Making of the Modern American Citizen, Oxford: Oxford University Press.

de Graauw, Els \& Vermeulen, Floris. (2016). Cities and the politics of immigrant integration: a comparison of Berlin, Amsterdam, New York City, and San Francisco. Journal of Ethnic and Migration Studies, 42:6, pp. 989-1012.

Favell, Adrian. (1998). Philosophies of Integration: Immigration and the Idea of Citizenship in France and Britain, Basingstoke: Macmillan.

Fitz-Gerald, John. (1918). National Aspects of Modern Language Teaching in the Present Emergency. Modern Language Journal, 3:2, pp. 49-62.

Flanders, Jesse Knowlton. (1925). Legislative control of the elementary curriculum, New York: Teachers College, Columbia University.

Gabaccia, Donna. (2000). Italy's Many Diasporas, Seattle: University of Washington Press.

Gabaccia, Donna; Hoerder, Dirk \& Walaszek, Adam. (2007). Emigration and nation-building during the mass migrations from Europe. In: Green, N. L. \& Weil, F. (eds.) Citizenship and Those Who Leave: The Politics of Emigration and Expatriation, pp. 63-90. Urbana, IL: University of Illinois Press.

Glick Schiller, Nina \& Çağlar, Ayse. (2009). Towards a Comparative Theory of Locality in Migration Studies: Migrant Incorporation and City Scale. Journal of Ethnic and Migration Studies, 35:2, pp. 177-202.

Hale, Douglas. (1980). The Germans from Russia in Oklahoma, Norman: Norman : University of Oklahoma Press.

Handschin, Charles Hart. (1913). The Teaching of Modern Languages in the United States, Washington, DC: Government Printing Office.

Helbich, Wolfgang. (1987). The Letters They Sent Home: The Subjective Perspective of German Immigrants in the Nineteenth Century. Yearbook of German-American Studies, 22, pp. 1-20.

--_. (1988). "Alle Menschen sind dort gleich..." Die deutsche Amerika-Auswanderung im 19. und 20. Jahrhundert, Düsseldorf: Schwann.

Helbich, Wolfgang \& Kamphoefner, Walter (eds.). (2004). German-American Immigration and Ethnicity in Comparative Perspective, Madison, WI: Max Kade Institute for German-American Studies, University of Wisconsin.

- - . (2006). How Representatitve are Emigrant Letters? An Exploration of the German case. In: Elliott, B., Gerber, D. \& Sinke, S. (eds.) Letters across borders : the epistolary practices of international migrants, pp. 29-55. Basingstoke: Palgrave Macmillan. 
Helbich, Wolfgang; Kamphoefner, Walter D. \& Sommer, Ulrike. (1988). Briefe aus Amerika: Deutsche Auswanderer schreiben aus der Neuen Welt 1830-1930 [Letters from America: German Emigrants Write from the New World 1830-1930], München: Beck.

Hornberger, Nancy H. (2002). Multilingual language policies and the continua of biliteracy: An ecological approach. Language Policy, 1:1, pp. 27-51.

Joppke, Christian. (2012). The Role of the State in Cultural Integraton: Trends, Challenges, and Ways Ahead. In: Stiftung, B. (ed.) Rethinking National Identity in the Age of Migration, pp. 124-42. Gütersloh: Verlag Bertelsmann Stiftung.

Joppke, Christian \& Morawska, Ewa T. (eds.). (2003). Toward Assimilation and Citizenship: Immigrants in Liberal Nation-States, Basingstoke: Macmillan.

Kamphoefner, Walter. (1987). The Westfalians: From Germany to Missouri, Princeton, N.J.: Princeton University Press.

- - . (2003). Learning from the "Majority-Minority" City. In: Sandweiss, E. (ed.) St. Louis in the century of Henry Shaw : a view beyond the garden wall, pp. 79-99. Columbia: University of Missouri Press.

Kazal, Russell. (2004). Becoming Old Stock: The Paradox of German-American Identity, Princeton, NJ: Princeton University Press.

Kellogg, Louise Phelps. (1918). The Bennett Law in Wisconsin. The Wisconsin Magazine of History, 2:1, pp. 3-25.

Kloss, Heinz. (1966). German-American Language Maintenance Efforts. In: Fishman, J., Nahirny, V., Hofman, J. \& Hayden, R. (eds.) Language Loyalty in the United States, pp. 233-7. The Hague: Mouton.

Krawatzek, Félix \& Müller-Funk, Lea. (this issue). Political Remittances and Transnationalism: Two Centuries of Links between 'Here' and 'There'. Journal of Ethnic and Migration Studies.

Krawatzek, Félix \& Sasse, Gwendolyn. (2018a). Integration and Identities: The Effects of Time in Migration, Migrant Networks, and Political Crises on Germans in the US. Comparative Studies in Society and History, 60:4, pp. 1029-65.

- - - (2018b). Migrantische Netzwerke und Integration: Das Transnationale Kommunikationsfeld deutscher Einwandererfamilien in den USA. Zeitschrift für vergleichende Politikwissenschaft, 12:1, pp. 211-28.

--- (2018c). The Simultaneity of Feeling German and Being American: Analyzing patterns of immigrant integration based on 150 years of private correspondence. Migration Studies.

Levitt, Peggy. (2001). The Transnational Villagers, Berkeley: University of California Press.

Manz, Stefan. (2014). Constructing a German Diaspora : The "Greater German Empire," 1871-1914, New York: Routledge.

McCafferty, Kevin \& Amador-Moreno, Carolina. (2012). A Corpus of Irish English Correspondence (CORIECOR). In: Migge, B. \& Ní Chiosáin, M. (eds.) Varieties of English around the world: New perspectives on Irish English, pp. 265-88. Amsterdam: John Benjamins Publishing Company.

Miller, Kerby. (2003). Irish Immigrants in the Land of Canaan : Letters and Memoirs from Colonial and Revolutionary America, 1675-1815, New York: Oxford University Press.

Moreton, Emma. (2012). Profiling the Female Emigrant: A Method of Linguistic Inquiry for Examining Correspondence Collections. Gender \& History, 24:3, pp. 617-46.

Pavlenko, Aneta. (2002). We have room for but one language here': Language and National Identity in the US at the Turn of the 20th Century. Multilingua, 21:2/3, pp. 163-96.

Ramsey, Paul. (2012). The Bilingual School in the United States: A Documentary History, Charlotte, NC: Information Age Pub.

Schlossman, Steven. (1983). Is There an American Tradition of Bilingual Education? German in the Public Elementary Schools, 1840-1919. American Journal of Education, 91:2, pp. 139-86.

Takenaka, Ayumi. (forthcoming). The Emergence of "Nikkeijin": A Historical Analysis of Japanese Diaspora Engagement. Journal of Ethnic and Migration Studies.

Tolzmann, Don Heinrich. (1994). Cincinnati's German heritage, Bowie, MD: Heritage Books.

--- (2006). Missouri's German heritage. In: Tolzmann, D. H. (ed.) Missouri's German heritage, pp. 109-34, 2nd ed. Milford, Ohio: Little Miami Pub. Co. 
Waldinger, Roger \& Feliciano, Cynthia. (2004). Will the new second generation experience 'downward assimilation'? Segmented assimilation re-assessed. Ethnic and Racial Studies, 27:3, pp. 376402.

Waldinger, Roger \& Green, Nancy. (2016). Introduction. In: Green, N. \& Waldinger, R. (eds.) A Century of Transnationalism: Immigrants and Their Homeland Connections, pp. 1-31. Urbana: University of Illinois Press.

Weber, Eugen. (1977). Peasants into Frenchmen: The Modernization of Rural France, 1870-1914, London: Chatto and Windus.

Werz, Nikolaus \& Nuthmann, Reinhard (eds.). (2004). Abwanderung und Migration in Mecklenburg und Vorpommern, Wiesbaden: VS Verlag für Sozialwissenschaften.

Wimmer, Andreas \& Glick Schiller, Nina. (2002). Methodological Nationalism and Beyond: NationState Building, Migration and the Social Sciences. Global Networks, 2:4, pp. 301-34.

Zeydel, Edwin. (1964). The Teaching of German in the United States From Colonial Times to the Present. The German Quarterly, 37, pp. 315-92. 